\title{
K FILOZOFII EKOLOGICKEJ CIVILIZÁCIE
}

\author{
RICHARD SŤAHEL, Filozofický ústav Slovenskej akadémie vied, Bratislava, SR \\ SŤAHEL, R.: Towards the Philosophy of the Ecological Civilization \\ FILOZOFIA, 75, 2020, No 10, pp. $815-831$
}

\begin{abstract}
The article presents the concept of ecological civilization and examines some of its aspects and its philosophical background. It points to the problem of understanding the concepts of culture and civilization, also in relation to the understanding of civilization as a further stage in the development of society. The ecological civilization should overcome the contemporary industrial civilization and its devastating effects on society and the environment. In examining the philosophical background of the concept, it focuses on Daoism and its relevance to contemporary, especially Chinese environmentalism. Finally, it deals with the differences between the Chinese and Western versions of the concept of ecological civilization, which identifies in a different understanding of the possibilities of ecological democracy and authoritarianism as tools for achieving an environmentally sustainable society.
\end{abstract}

Keywords: Environmental crisis - Ecological civilization - Ecological democracy China - Daoism

Koncept ekologickej civilizácie alebo ekocivilizácie je v našom environmentálnom a rovnako aj filozoficko-politickom myslení prakticky neznámy. V súčasnosti pritom ide o jednu z najdynamickejšie sa rozvíjajúcich iniciatív environmentálneho myslenia, ktorou sa najl'udnatejšia krajina sveta už viac ako desat'ročie snaží sformulovat' svoju odpoved' na výzvy antropocénu. Pozoruhodná je aj tým, že na rozdiel od väčšiny západných environmentálnych konceptov, čínska verzia konceptu ekologickej civilizácie už nie je len teoretickým modelom, ale aj prakticko-politickou stratégiou, vládnym programom a víziou budúcnosti. Stala sa totiž súčast’ou ideológie Komunistickej strany Číny, Ústavy Čínskej l’udovej republiky, ${ }^{1}$ ale je tiež štátnou politikou a zároveň

\footnotetext{
${ }^{1}$ V roku 2007 17. zjazd Komunistickej strany Číny (KSČ) ako ciel' d’alšieho rozvoja vytýčil spoločnosti budovanie „ekologickej civilizácie“. Od novembra 2007 je koncept ekologickej civilizácie prezentovaný ako súčast' oficiálnej vládnej politiky, a tiež ideológie KSČ. V roku 2012 bol integrovaný do pät'bodovej stratégie, o ktorú sa opierala čínska trinásta pätročnica. Súčast’ou ústavy Čínskej l'udovej republiky (ČL'R) je od roku 2012. V roku 2013 bol úradujúcim prezidentom potvrdený ako hlavný rámec pre štátne environmentálne politiky a legislatívu. Prehl'adnú časovú os inštitucionalizácie konceptu ekologickej civilizácie v politickom a ústavnom systéme ČL'R pozri UNEP $(2016,4)$. V roku 2018 bolo postavenie konceptu ekologickej civilizácie v ústave ČLR ešte väčšmi posilnené, takže tento koncept je fakticky jedným zo základných ústavných princípov.
} 
imagináciou budúcej spoločnosti, teda ciel’om, ku ktorému má smerovat' nielen vývoj Číny, ale v ideálnom prípade aj globálnej civilizácie. ${ }^{2}$

Tento koncept bol v Č́ne prvýkrát formulovaný v prvej polovici osemdesiatych rokov minulého storočia (Pan 2014, 36), a to v nadväznosti na model „ekologickej kultúry“ (Lipickij 1984), ktorý vznikol ešte v bývalom Sovietskom zväze. Dalším z podnetov pre čínsku verziu konceptu ekologickej civilizácie však bol R. Morrison a jeho publikácia Ecological democracy (1995), v ktorej autor sformuloval dôvody transformácie industriálnej civilizácie na civilizáciu ekologickú a načrtol aj jej atribúty a možné spôsoby jej dosiahnutia. Čínska veria konceptu je však do vel'kej miery aj výsledkom snahy filozoficky uchopit' environmentálne dôsledky prudkého rozvoja hospodárstva, rovnako ako procesy industrializácie a urbanizácie, v rámci ktorých sa za necelých štyridsat' rokov tradične rurálna a agrárna kultúra Číny zmenila na urbánnu a priemyselnú, ${ }^{3}$ a to vrátane negatívnych sociálnych a environmentálnych dôsledkov takéhoto extenzívneho rozvoja. ${ }^{4}$ To vyvolalo aj potrebu formulovat' úplne nové pravidlá, upravujúce medzil'udské a spoločenské vzt’ahy. V súvislosti s rozsiahlou devastáciou životného prostredia a širokospektrálnym znečistením, ktoré urbanizácia a industrializácia od roku 1978 spôsobili, mnohí čínski autori otvorene priznávajú, že Č́na v plnej miere aplikovala takzvaný západný model rozvoja, teda že stotožnila ekonomický rast s rozvojom, čo platilo prinajmenšom prvých tridsat' rokov transformácie. ,,Najprv znečistenie, potom jeho kontrola; najprv devastácia, až potom obnova', to je, zdá sa, začarovaný kruh, ktorému sa v procese industrializácie nedá vyhnút' v žiadnej krajine či regióne" (Xie, Pan 2018, 11). V neposlednom rade je koncept výsledkom úsilia revitalizovat' tradičné čínske myšlienkové koncepty a zároveň na ne nadviazat' všade tam, kde je to možné.

Za pravdepodobne najvýznamnejšieho predstavitela čínskej verzie konceptu ekologickej civilizácie možno považovat' J. Pana. Podl'a neho je ekologická civilizácia „kombináciou ekológie, konceptom prírody, civilizácie a človeka a jadro ekologickej civilizácie je vo vzt’ahu človeka a prírody“ (Pan 2016, 36). Zároveň je rozvinutím tradičného konceptu „harmónie medzi človekom a prírodou“, ktorý je podla

\footnotetext{
${ }^{2} \mathrm{~K}$ čínskemu chápaniu globalizácie pozri Hrubec (2020a).

${ }^{3}$ V roku 1978, ked' sa v Č́ne začala uplatňovat' nová hospodárska a rozvojová politika, bola miera urbanizácie Č́ny 19,72 \%, do roku 2016 vzrástla na 57,35 \%. Mestská populácia vzrástla zo 170 mil. na 770 mil. l'udí, pričom počet miest vzrástol zo 193 na 656 a stále sa budujú d’alšie. V roku 1981 zaberala mestská zástavba $7000 \mathrm{~km}^{2}$, v roku 2015 už 49000 km² Č́ny. Len medzi rokmi 2010 a 2015 vzrástla mestská populácia o 101,37 mil. obyvatel'ov. Do roku 2030 má urbanizácia Číny dosiahnut' $70 \%$. V mestách pritom už v súčasnosti vzniká až $80 \%$ čínskej hospodárskej produkcie (Xie, Pan 2018, 85 -98). V urbanizácii a industrializácii, a tiež v znečistení a devastácii životného prostredia tak Č́na stihla za 40 rokov to, čo Západu trvalo aspoň 200, niekde až 300 rokov.

${ }^{4}$ Čína sa v roku 2007 stala najväčším svetovým producentom $\mathrm{CO}_{2}$, ked' v jeho produkcii predbehla Spojené štáty americké. Významne k tomu prispelo nielen zvyšovanie životnej úrovne, teda aj celkovej spotreby obyvatel'ov Číny, ale aj globalizácia, v rámci ktorej bolo do Číny presunutých množstvo výrobných kapacít, ktoré pôvodne produkovali skleníkové plyny a d’alšie znečistenie v Európe a v Severnej Amerike. A. Gare $(2012,21)$ v tejto súvislosti pripomína, že ,životné prostredie Číny je ničené produkciou spotrebného tovaru pre bohatých, z ktorých väčšina nie sú Číñania, ale žijú v iných krajinách".
} 
neho jedným z kl'účových východísk čínskeho filozofického myslenia. Tento tradičný koncept totiž už vo svojich najstarších prameňoch pracuje s poznaním, že „l'udské základné materiálne potreby sú obmedzené, zatial' čo l'udské túžby môžu byt' nekonečné" (Pan 2016, 37). Práve snaha naplnit' ničím neobmedzované l'udské túžby sa ukazuje ako jedna z hlavných príčin devastácie životného prostredia. Najväčšou slabinou agrárnej a industriálnej civilizácie je potom neschopnost' riešit' problém neudržatel'nosti (Pan 2016, 41), teda spôsobu využívania prírodných zdrojov, ktorého dôsledkom je devastácia životného prostredia a vyčerpanie prírodných zdrojov. Preto najvýznamnejším princípom konceptu je udržatel'nost' ekologickej civilizácie.

Ekologická civilizácia však nemá byt' opakom civilizácie industriálnej. Má byt' jej pokračovaním, tak ako je priemyselná civilizácia pokračovaním tej agrárnej. Po transformácii z agrárnej na priemyselnú civilizáciu má Č́́na ambíciu pokračovat' v transformovaní na ekologickú civilizáciu, a to v zmysle konceptu, ktorý proklamuje, že chce íst' ovel'a d'alej ako koncept udržatel'ného rozvoja. Koncept ekologickej civilizácie je tak definovaný ako nová rozvojová paradigma, zároveň však určuje limity rozvoja (red lines), ${ }^{5}$ a to napríklad definovaním rozlohy ornej pôdy, pastvín, mokradí, lesov či chránených území, ktoré musia byt' určite zachované, respektíve ktoré nesmú byt' obetované industriálnej, dopravnej či obytnej infraštruktúre, ale musia byt' ponechané na produkciu potravín (orná pôda, pastviny) alebo na samovývoj a na zachovanie prirodzených biologických a regeneračných procesov ${ }^{6}$ (Xie, Pan 2018, 30 - 36). Kl'účovým kritériom na takomto základe koncipovaných verejných politík má byt' udržatel'nost', teda už nie rast HDP. V ekonomickej rovine koncept počíta s dosiahnutím stabilného stavu ekonomiky ${ }^{7}$ Pan 2016, 147 - 164) a vysokej úrovne recyklácie, ${ }^{8}$ rovnako ako s takzvanou nízkouhlíkovou ekonomikou. ${ }^{9}$ Koncept pracuje aj s pojmom ekologickej bezpečnosti, ktorú dokonca chápe ako súčast' priorít štátnej bezpečnostnej politiky (Pan 2016, 124 - 127). Aplikáciou tohto konceptu sa má vyriešit rozpor medzi rozvojom a rastom znečistenia a devastácie životného prostredia. ${ }^{10}$

\section{K pojmom kultúra a civilizácia}

Nie je však slovné spojenie ekologická civilizácia vnútorne rozporné? Pojmy kultúra či civilizácia sú v západnej filozofickej tradícii zväčša chápané ako opak prírody. Už

\footnotetext{
${ }^{5} \mathrm{~K}$ tomu pozri (Jiang, Bai, Wong, Xu, Alatalo 2019).

${ }^{6}$ Napríklad mokrade, prírodné rezervácie alebo iné územia, dôležité pre zachovanie biodiverzity a prirodzených evolučných procesov.

${ }^{7}$ Tzv. steady-state economy, ktorý sa má stat' novým normálom (new normal).

${ }^{8}$ Tzv. recycle economy je $\mathrm{v}$ Číne jednou z priorít, ktorá je presadzovaná na všetkých stupňoch verejnej správy.

${ }^{9}$ Súčastou tzv. low-carbon economy je rozsiahly program výstavby vysokorýchlostných železníc, elektrifikácie autobusovej i automobilovej dopravy a štátom vynucované zatváranie uhol'ných baní a elektrární a ich nahrádzanie veternými a solárnymi zdrojmi energie.

${ }^{10}$ Odpojenie rozvoja, teda rastu životnej úrovne, fakticky ale výroby a spotreby od rastu znečistenia, tzv. decoupling je kl'účovým faktorom pre súčasné zvládnutie environmentálnej a sociálnej krízy. Viaceré štúdie však poukazujú na to, že tzv. zelený rast je vel'mi pravdepodobne nedosiahnutel'ný, ak nie priamo nemožný (Heberl at al 2020).
} 
len použivanie týchto pojmov predpokladá dualistický, opozitami vymedzený rámec myslenia. Samotná dištinkcia medzi kultúrou a civilizáciou na jednej strane a prírodou na druhej vychádza z antropológie vyčleňujúcej človeka z prírody, či dokonca stavajúcej človeka proti prírode. Práve z takejto kontrapozície plynie potreba „boja“ s prírodou či v lepšom prípade chápanie prírody len ako „zdroja“ rozvoja ludskej spoločnosti či jej bohatstva a „priestoru“, v ktorom sa odohrávajú l’udské dejiny. V takomto chápaní je ciel'om civilizácie „oslobodenie“ spod moci prírody - a to tak vonkajšej (počasie, klimatické výkyvy, choroby), ako i vnútornej (pudy, limity dané vekom, pohlavím, kondíciou atd’.). Koncept „udržatel'ného rozvoja“ neprekračuje tento rámec, stále počíta s rozvojom ako samozrejmost'ou, rozvoj stotožňuje s rastom, len apeluje na to, aby bol rozvoj ohl'aduplný k možnosti napíňania potrieb budúcich generáciii ${ }^{11}$ (World Commission on Environment and Development 1987).

Pan upozorňuje na to, že v starovekej Číne bolo chápanie kultúry a civilizácie odlišné. „Kultúra je predovšetkým rozvinutie vnútorných schopností či cností jednotlivca, zatial' čo civilizácia zahíňa materiálny i duchovný obsah a je ich kombináciou“ (Pan $2015,34)$. Poukazuje pritom na to, že v západných jazykoch je význam pojmu civilizácie odvodzovaný od latinského civis a civitas, teda občan a mesto (pospolitost'). Civilizácia je tak väššmi chápaná ako spoločenské usporiadanie vychádzajúce z princípu občianstva (teda nie rodu, rasy, stavu či triedy). Pojem civilizácia je tiež spájaný so životom signifikantnej časti populácie v mestách, respektíve s urbanizmom ako sociálno-politickým javom i ako úrovňou technického rozvoja (schopnosti plánovat', budovat' a prevádzkovat' mestskú infraštruktúru) a organizačno-administratívnych znalostí, respektíve zručností. Práve v tejto súvislosti sa črtá jeden z podstatných významových aspektov pojmu ekologická civilizácia. Intenzívna urbanizácia a zmena štruktúry obyvatel'stva Č́ńn, ktorá bola po tisícročia rurálnou a agrárnou civilizáciou, dáva pojmu ekologická civilizácia d’alší, nie nepodstatný významový aspekt.

Podl'a Pana však v čínštine pojem ,civilizácia viac zdôrazňuje vnútornú kultivovanost' osoby a schopnost' jej d'alšieho zlepšovania, zatial' čo v európskych jazykoch sa väčší dôraz kladie na vonkajšie vystupovanie, medzil'udské vzt'ahy alebo sociálne

\footnotetext{
${ }^{11}$ Koncept udržatel'ného rozvoja vznikol v dôsledku pochopenia rozporu medzi potrebami ekonomického a sociálneho rozvoja, teda zvyšovania životnej úrovne a potrebou ochrany životného prostredia, teda ako snaha o zladenie týchto, v mnohom protikladných procesov. Ako ukazuje D. Moellendorf (2011), aplikácie tohto konceptu v niektorých medzinárodných dohodách dokonca vyústila do konštituovania práva na udržatel'ný rozvoj. Sám koncept, ale aj dôsledky snahy o jeho praktické uplatnenie, však čelia rozsiahlej kritike. Napríklad J. Lovelock $(2014,108)$ poukazuje na to, že „udržatel'ný rozvoj jednoducho znamená rast“, L. Sklair (2019) vysvetl'uje, ako bol tento koncept inkorporovaný do naratívu obhajujúceho záujmy korporácií, čím sa stal súčast'ou ideológií industrializmu a konzumerizmu. Čoraz rozsiahlejšia devastácia infraštruktúry i ekosystémov, ktorú spôsobujú klimatické zmeny, pritom v mnohých oblastiach sveta ohrozujú fyzické prežitie celých populácií, pretože vlády postihnutých krajín už neraz nie sú schopné zabezpečovat' ani záchranné operácie, či aspoň distribuovat humanitárnu pomoc. Trvat' $v$ tejto situácii na „udržatel'nom rozvoji“ ako zmysluplnom koncepte je prinajmenšom znakom ignorovania reality (St’ahel 2019).
} 
skupiny“ (Pan 2015, 34). ${ }^{12}$ V každom prípade však platí, že „civilizácia je výsledok interakcie človeka a prírody, pričom však žiadna civilizácia nemôže transcendovat' prírodu“ (tamže). Práve tento poznatok, je pre koncept ekologickej civilizácie klúčový.

Rozlišovanie agrárnej a priemyselnej civilizácie však vychádza z rozdielu v spôsobe využívania prírodných zdrojov a produkcie bohatstva $v$ spoločnosti. Kontrastovanie týchto dvoch vývojových štádií civilizácie s ekologickou civilizáciu, ${ }^{13,14}$ ktorej hlavným atribútom má byt' udržatel'nost', však zvýrazní práve spôsob využívania prírodných zdrojov ako klúčový významový aspekt. Civilizáciu tak možno chápat' aj ako výsledok nadprodukcie, ktorý umožňuje dlhodobé uvol'ňovanie časti populácie z procesu produkcie základných potrieb (potrava, ošatenie, bývanie) a zároveň ako výsledok dostupnosti vel'kého množstva surovín a energonosičov i technológí ich t’ažby, dopravy a využitia. Dôležitým predpokladom vzniku akejkol'vek civilizácie však bol stabilný klimatický režim holocénu, ktorý po skončení poslednej doby l'adovej umožnil usadnutý spôsob života, ktorý bol spojený s pol’nohospodárstvom produkujúcim prebytok potravín. Práve tento základný klimatický predpoklad vzniku civilizácie je teraz ohrozený novým, nestabilným klimatickým režimom antropocénu. Už len tento fakt nevyhnutne vedie k potrebe nanovo premysliet' predpoklady existencie civilizácie a možné zmeny jej imperatívov a organizačných princípov tak, aby civilizácia mohla existovat' aj v antropocéne, teda $\mathrm{v}$ iných klimatických podmienkach, než ktoré umožnili jej vznik a rozvoj až do štádia globálnej industriálnej civilizácie. Civilizáciu totiž ohrozuje jej vlastný úspech $\mathrm{v}$ podobe ovládnutia celého sveta a jeho transformácie pre potreby „civilizovaného" spôsobu života a negatívnych vedlajších, zväčša nezamýšlaných, ale hlavne nepredpokladaných dôsledkov ludských aktivít.

\footnotetext{
${ }^{12}$ Diskusia o povahe kultúry a civilizácie a ich vzájomnom vzt'ahu je samozrejme ovel’a komplexnejšia, a to nielen v rámci západného, ale aj slovenského diskurzu. Napríklad J. Piaček (2014) vymedzuje vzt’ah kultúry a civilizácie ako vzt’ah antagonistický, a zároveň tvoriaci pozadie jeho konceptu sykriticizmu. Kultúru pokladá za ontologicky najvýdatnejší spôsob bytia človeka na svete, a zároveň za vedomé pokračovanie prírody. Civilizáciu chápe ako podklad kultúry, ale zároveň ako odtrhnutú od kultúry. Civilizácia totiž kultúru predstihla a pri svojej vít’aznom úsilí ovládnut' svet postupuje zväčša nekultúrne - vojensky, vykorist'ovatel'sky, technologicky, imperiálne, a preto aj smrtonosne.

${ }^{13}$ Rozlišovanie agrárnej, industriálnej a ekologickej civilizácie prinajmenšom implicitne obsahuje filozofiu dejín, postavenú na forme a spôsobe využívania prírody človekom. Z podobného kritéria vychádza I. Dubnička (2007) pri rozlišovaní morálnych systémov vzt'ahu človeka a prírody v kultúrach lovcov a zberačov, pastierov a rol'níkov, a napokon v moderných industriálnych kultúrach.

${ }^{14}$ A. Gare $(2012,11)$ v tejto súvislosti poukazuje na to, že v Číne, ktorá sa označuje za socialistickú krajinu je ekologická civilizácia definovaná ako štádium rozvoja spoločnosti, nasledujúce po prekonaní industrializmu, a nie kapitalizmu, ako sa by sa očakávalo od krajiny, ktorá sa oficiálne riadi ideológiou marxizmu. Ako však poznamenáva D. A. Bell „tie prvky marxizmu, ktoré mali v (čínskej) spoločnosti výraznejšiu odozvu - dôraz na materiálny blahobyt a odpor voči abstraktnému mysleniu - sa uchytili práve preto, že mali konfuciánske základy“ (Bell 2010, 10). Podl’a G. Parkesa (2020) je dokonca skutočnou ideológiou vládnucej strany v Číne konfucianizmus, a nie komunizmus, ktorý má v názve. O nutnosti prekonania kapitalizmu ako predpokladu transformácie industriálnej civilizácie na ekologickú tak paradoxne častejšie uvažujú západní ako čínski autori.
} 
V neposlednom rade je civilizácia tiež výsledkom dlhodobého hromadenia poznatkov a schopnosti ich zaznamenávania a medzigeračného prenosu. Tá si vyžaduje kultúrnu, a do značnej miery aj politicko-organizačnú kontinuitu. Práve tento aspekt významu pojmu civilizácie zdôrazňujú čínski autori, a to poukazovaním na kontinuitu čínskej civilizácie, na viac ako dvetisícročnú kontinuitu čínskeho štátu i na jav, ktorý je v l'udských dejinách ojedinelý a ktorým má byt' zastrešenie prakticky celej čínskej kultúry jedným štátom. Práve v tomto kontexte (aj ked' samozrejme nie len v ňom) treba hl'adat' zmysel úsilia čínskych autorov poukazovat' na to, že východiská konceptu ekologickej civilizácie možno identifikovat' v klasických čínskych myšlienkových tradíciách - taoizme, konfuciazme i sinizovanej verzii budhizmu (Xie, Pan 2018, 293 - 294), respektíve v nimi vyjadrenej predstave o vzt'ahu človeka a prírody. A to napriek tomu, že industriálna civilizácia je fakticky civilizáciou globálnou. ${ }^{15}$

\section{Filozofické východiská}

Kým západný environmentalizmus má tendenciu hl'adat' vzory harmonického spolužitia s prírodou v kultúrach, respektíve $\mathrm{v}$ spôsobe života prírodných národov, niektoré prúdy dokonca v budhizme (jeho západnej interpretácii), ten čínsky sa obracia k vlastným kultúrno-filozofickým koreňom, a to najmä ku konfucianizmu a taoizmu. Prinajmenšom z pragmatického hl'adiska, teda z perspektívy väčšej prijatel'nosti medzi obyvatel'mi Č́ny i kompatibility s čínskym socio-ekonomickým a politicko-administratívnym modelom organizácie spoločnosti ${ }^{16}$ je takýto prístup pochopitelný. Problém pochopenia a interpretácie čínskej filozofie $\mathrm{v}$ kontexte čínskej kultúry, a to najmä pokial' ide o jej staroveké texty ${ }^{17}$ však ostáva stále aktuálny, ${ }^{18}$ a to aj pri snahe o iden-

\footnotetext{
${ }^{15} \mathrm{~K}$ tomu pozri St'ahel (2016a, 105 - 117).

${ }^{16} \mathrm{~K}$ charakteristike, prameňom a súčasnej relevancii čínskeho modelu organizácie spoločnosti pozri Bell (2015), a tiež Hrubec (2020b).

${ }^{17}$ Už prvé interpretácie čínskej filozofie, náboženstva a ich kultúrneho kontextu boli v Európe vel'mi významne poznačené nielen jazykovou bariérou, ale aj snahou o „napasovanie“ čínskych filozofických, spoločenských a politických reálií do európskych pojmov a rámcov myslenia (Bondy 1993a, 104) a v neposlednom rade využívaním týchto interpretácií v európskych teologických a ideologických sporoch, čo v rôznych formách a intenzite pretrváva do súčasnosti. Primárne však bolo čínske myslenie skúmané s úmyslom nájst' možnosti a spôsoby, ako Č́ńn obrátit' na krest’anskú vieru, ked’že do devätnásteho storočia neboli európske koloniálne mocnosti schopné Čínu vojensky ani ekonomicky ovládnut', pokúšali sa o to aspoň ideologicky. Ako ukazuje B. Horyna, nevyhol sa tomu ani G. W. Leibniz, ktorý síce nebol tým, kto pre západnú kultúru objavil Čínu a jej filozofiu, ale rozhodne bol prvým reprezentantom klasickej európskej filozofie, ktorý sa nielen vedome zriekol eurocentrizmu (Horyna 2020,147), ale dokonca poukázal na to, že popri západnej, teda európskej, existuje aj východná, prevažne čínska kultúra, pričom obe treba považovat' za významné pre celý svet a treba ich preto chápat' ako rovnocenné (Horyna 2020, 157 - 158) čo v západnom diskurze doposial' nie je všeobecne prijímaný postoj. K potrebe, ale tiež peripetiám interkultúrneho dialógu vo vzt’ahu k Č́ne pozri aj Dunaj (2013 a 2020).

${ }^{18}$ Filozofickú reflexiu konceptu ekologickej civilizácie z európskej, respektíve západnej perspektívy komplikuje nielen jazyková bariéra, ale aj nejasná hranica medzi religióznym a filozofickým aspektom tradičného čínskeho svetonázoru. E. Bondy v tejto súvislosti poukázal na to, že ,čínska spiritualita je od najstarších dôb spiritualita areligiózna“" (Bondy 1993a, 99), čo sa ukazuje ako problém aj pri snahe
} 
tifikovanie relevantných filozofických východísk čínskej verzie konceptu ekologickej civilizácie.

Čínska verzia konceptu ekologickej civilizácie síce nadväzuje na viaceré ,západné “ koncepty (udržatel'ný rozvoj, ekomarxizmus, ekologická demokracia ${ }^{19}$ ), ale zároveň aj na tradičné čínske spôsoby myslenia a výkladu sveta. Vo filozofickej rovine je dokonca vnímaný ako súčast' renesancie tradičných čínskych spôsobov myslenia a interpretácie sveta, pričom vedome nadväzuje najmä na konfucianizmus, ${ }^{20}$ taoizmus ${ }^{21}$ a čiastočne aj čínsky budhizmus. ${ }^{22}$ Predovšetkým čínski autori pritom zdôrazňujú, že $\mathrm{v}$ žiadnom z týchto tradičných čínskych myšlienkových prúdov neprevážil západný antropocentrizmus, ktorý vydel'uje človeka z prírody, respektíve vytvára dichotómiu človeka a prírody, ale naopak, inherentnou súčastou všetkých tradičných čínskych konceptov bol obraz človeka ako súčasti prírody a len vel'mi zriedkavo spochybňovaným ideálom bolo hladanie harmónie človeka s prírodou a neposlednom rade aj človeka so spoločnost'ou. ${ }^{23}$

o interpretáciu fillozofických východísk konceptu ekologickej civilizácie. Schönfeld a Chen (2019, 5) dokonca zdôrazňujú, že klasická čínština vôbec nemá pojmy ekvivalentné pojmom náboženstvo a filozofia. Ich ekvivalenty do súčasnej čínštiny zaviedli zahraniční akademici v rámci svojho štúdia čínskej kultúry ako neologizmy. Skôr ako Sokratovskou „láskou k múdrosti“ je čínska filozofia „učením múdrosti“, pre ktoré nie je dištinkcia medzi profánnym a sakrálnym určujúca, respektíve je „konceptuálnym kontinuom s absenciou demarkácie medzi filozofiou a náboženstvom“(tamže). Pre západného pozorovatel'a je preto prekvapivé, či dokonca neuveritel'né, že by sa na formulovaní, ale aj propagovaní a praktickom uskutočňovaní ideologického konceptu i podla neho realizovanej praktickej politiky štátu, hlásiaceho sa k marxizmu, mohla intenzívne podiel'at' aj Č́nska taoistická asociácia, teda zo západnej perspektívy náboženská organizácia, ktorá však intenzívne spolupracuje aj s vládou ČLR. K tomu pozri (Lemche, Miller 2019) a tiež (Schönfeld, Chen 2019). V tejto súvislosti treba zdôraznit', že náboženstvo v európskom zmysle slova nebolo a nie je súčast'ou čínskej kultúry. „Skutočný polyteizmus zmizol v Číne už dávno na úsvite historickej doby a monoteizmus sa nikdy nevyvinul. Číñania si vystačili s etikou - a to etikou l'ud'mi vytvorenou, nie nadiktovanou odniekial' zhora - a s vágnou ontologickou predstavou prirodzeného chodu vecí, ktorý bol najlepšie vyjadrený v koncepcii a termíne TAO. V tom je súčasne vel'kost' i slabost' čínskej myšlienkovej tradície“" (Bondy 1993b, 140 - 141).

${ }^{19}$ J. Pan sa odvoláva na prácu R. Morrisona (1995) Ecological Democracy (Pan 2014, 34). Pracuje však aj s prácami ako sú The limits to growth (Meadows et al. 1972) či Collapse: How societies choose to fail or succeed (Diamond 2005). V celom koncepte je výrazne badatel'né pochopenie rizík spojených s konečnost'ou zdrojov a možnost'ou kolapsu civilizácie. Koncept tak možno interpretovat' aj ako snahu nájst' taký model organizácie vysoko komplexnej spoločnosti, ktorý by umožnil vyhnút' sa kolapsu (prinajmenšom čínskej) civilizácie.

${ }^{20} \mathrm{~K}$ relevancii konfucianizmu v súčasnom čínskom filozofickom myslení a snahe o porozumenie v Č́ne prebiehajúcim spoločenským procesom pozri napr. Bell (2010, 2015), Dunaj (2016, 2017), Kögler, Dunaj (2018), Kreuzzieger (2019), a tiež Parkes (2020).

${ }^{21}$ Pozri napríklad Lu (2017).

${ }^{22}$ Pozri Pan $(2015,35)$, Xie, Pan $(2018,293)$.

${ }^{23}$ Sociálny, respektíve sociálno-politický rozmer konceptu ekologickej civilizácie je rovnako dôležitý ako ekonomický či environmentálny. Ved' najbohatšie polpercento svetovej populácie (teda asi 40 miliónov l'udí) svojim nadspotrebným životným štýlom produkuje až $14 \%$ svetových emisií skleníkových plynov. Na druhej strane najchudobnejších $50 \%$ svetovej populácie je zodpovedných len za $10 \%$ emisií (Wiedmann, Lenzen, Keyßer et al. 2020). Už len táto socioenvironmentálna nespravodlivost' má potenciál rozvrátit' globálnu civilizáciu sociálnym výbuchom. Koncept 
Z perspektívy súčasného environmentalizmu sa ako „najzelenší“ $z$ filozofických smerov starovekej Č́ny javí taoizmus. ${ }^{24}$ Vo filozofickej rovine je vyjadrením tradičného čínskeho chápania sveta ako vzájomne súvisiaceho živého systému, či dokonca organizmu (Overmayer 1999) tvoreného nebom, zemou a človekom ako tromi neoddelitel'nými komponentmi jednotného univerza, navzájom previazanými dialektickým procesom nestáleho vzájomného ovplyvňovania a vyvažovania. Pan v tejto súvislosti odkazuje na posledné štvorveršie dvadsiatej piatej kapitoly Tao Te t'ingu, ktorého autorstvo sa pripisuje anonymnému autorovi známemu ako Lao-c' (Starý majster):

$$
\begin{aligned}
& \text { Zákony Človeka podmieňuje Zem, } \\
& \text { Zákony Zeme podmieňuje Nebo, } \\
& \text { Zákony Neba podmieňuje Cesta Tao, } \\
& \text { A Cesta Tao je sama zo seba! }
\end{aligned}
$$

$$
(\text { Lao-c' 1993, 35) } 25
$$

Podl'a Pana sa Lao-c' pokúša vyjadrit' vzt'ahy medzi človekom a prírodou a pravidlá, ktorými sa tieto vzt'ahy riadia. Toto štvorveršie teda znamená, že l'udia žijú, pracujú a reprodukujú podl'a zákonov zeme; zem sa mení podl'a ročných období, a tým produkuje rozličné formy života podl'a zákonov neba; nebo funguje a mení sa podl'a princípov Cesty Tao; zatial' čo Tao nasleduje zákony prírody, pričom necháva prírodu uberat' sa svojou cestou. Toto videnie sveta a princípov jeho fungovania neskorší čínski autori rozpracovali do filozofického systému „harmónie medzi človekom a prírodou“, ktorý je podl'a Pana v zretel'nom kontraste k západnej filozofii využívania rozvinutej vedy na dobýjanie, plienenie a drancovanie prírody. Pre súčasnú industriálnu civilizáciu z toho podl'a Pana plynie, že vzt'ah človeka a prírody nemá stát' na úsilí človeka menit' a transformovat' prírodu, ale na rešpektovaní prírody a konaní v súlade $\mathrm{s}$ jej zákonitost’ami (Pan 2016, 35). Vedecká dimenzia prírodnej ekológie (natural ecology) pochádza zo západu, filozofická dimenzia humánnej ekológie (human ecology) vznikla v Číne a jej prvé formulácie možno podl'a Pana nájst' práve v Tao Te t’ingu (tamže).

Schönfeld a Chen $(2019,6)$ v súvislosti s touto, ale aj d’alšími pasážami Tao Te tingu konštatujú, že ide o špecifickú formu naturalizmu, ktorá je výnimočne vhodná na zvládnutie súčasnej environmentálnej krízy. Za jedinečný vklad taoistickej perspektívy vnímania vzt’ahu človeka, respektíve kultúry a prírody do konceptu ekologickej civilizácie považujú motívy, ktoré sú podl'a nich identifikovatel’né aj v súčasnom taoizme: vnímanie vzt’ahu prírody a kultúry ako kontinua, normatívny charakter prírodných faktov, umiernený antropocentrizmus a v neposlednom rade evolučná koncepcia prírody

ekologickej civilizácie je preto tiež kritikou existujúceho globálneho ekonomicko-politického systému a zároveň snahou o sformulovanie vízie takého spoločenského usporiadania, ktoré by mohlo nahradit' to súčasné, interpretované aj západnými autormi ako korporatokracia. K tomu pozri Gare (2014a, 2014b, 2017a, 2017b, 2018) alebo Ahearne (2013). Koncept ekologickej civilizácie má teda vel’a styčných bodov s politickou ekológiou či sociálnou ekológiou.

${ }^{24}$ Pozri Miller (2017), ale aj Gare (2013).

${ }^{25}$ Citované podl'a prvého slovenského prekladu M. Čarnogurskej a E. Bondyho. 
i človeka. Príroda je chápaná ako „konečný rámec, integrujúci všetko vrátane kultúry“. V tejto súvislosti konštatujú, že charakteristickou črtou antropocénu je práve rozpúšt’anie hranice oddel'ujúcej kultúru a prírodu (tamže), teda tej dištinkcie, ktorá bola, a do značnej miery doposial' je, charakteristická pre západnú kultúru, rovnako ako pre industriálnu civilizáciu. Zároveň poukazujú na to, že evolúcia prírody je súčast'ou kozmológie a ontológie taoizmu, a preto tak ako sa vyvíja príroda, musí sa menit' aj civilizácia. Podl'a nich „taoizmus vo svojej starovekej ontológii anticipuje základné prvky štandardného vedeckého modelu najmä v oblasti ekológie a evolúcie“ (Schönfeld, Chen 2019, 14).

Tao Te t'ing, samozrejme, obsahuje množstvo d'alších pasáží, ktoré možno interpretovat' $\mathrm{v}$ súlade s tézami súčasného environmentalizmu, to však nie je ciel'om tejto štúdie. Podstatné je, že Tao Te ting vyjadruje kozmologický i ontologický model sveta, „podaný na svoju dobu vel’mi koherentne“ (Bondy 1993a, 101), ktorý svet vidí ako vyvíjajúce sa kontinuum medzi prírodou a človekom, respektíve kultúrou. ${ }^{26}$ „Zatial' čo grécka a indická filozofia hl'adala usilovne a v najrôznejších variantoch ,pevný bod“, nemenný základ skutočnosti (bud' v božstve, ktoré tvorí svet, či v nejakej prapodstate imateriálnej či materiálnej -, z ktorej svet takým či onakým spôsobom vyplýva, alebo sa formuje), čínska filozofia videla (a vidí) skutočnost' ako proces" (Bondy 1993a, 100). Práve takéto videnie skutočnosti sa javí ako ovel'a vhodnejšie východisko pre pochopenie a konzekventné premyslenie poznatkov súčasných vied o Zemi, ktoré sa snažia uchopit' evolúciu človeka i biosféry, atmosféry, hydrosféry a kryosféry ako navzájom prepojený a podmienený, nikdy nekončiaci proces, ako umožňuje „európska filozofická tradícia, vychádzajúca v podstate zo substančného modelu skutočnosti““ (Bondy 1993a, 104). To by aspoň čiastočne vysvetl’ovalo, prečo svetonázor postavený na substancialistických, pevný bod (nemennú, večnú podstatu) hl'adajúcich ontologických konceptoch, má aj tvárou $\mathrm{v}$ tvár prebiehajúcim procesom klimatickej zmeny a masového vymierania rastlinných a živočíšnych druhov problém pripustit', že je niečo také vôbec možné a že príčinou týchto javov môže byt' človek a ich dôsledkom taká radikálna zmena globálneho klimatického systému, ktorá znemožní d’alšiu existenciu civilizácie.

Z hladiska konceptu ekologickej civilizácie ako svetonázoru, ktorý vychádza z pochopenia človeka (l’udstva) ako súčasti pomerne l’ahko zranitel'nej prírody, či presnejšie komplexnej siete závislostí planetárneho systému života a jeho predpokladov, je však dôležité to, že konfucianizmus, a ani čínsky budhizmus taoizmom vyjadrený svetonázor (integrujúci kozmológiu, ontológiu i etiku) nespochybnili. I. Dubnička v tejto súvislosti hovorí o čínskych univerzalistických náboženstvách, pri ktorých došlo $\mathrm{k}$ zvláštnej synkréze, takže ich možno označovat’ aj ako „tri náuky v jednom“. Podl'a Dubničku „sú najtypickejšie pre čínsku spoločnost' a vo vel'kej miere determinovali jej tradície, no aj ,filozofickú' a ,politickú' mentalitu Číňanov“ (Dubnička 2013, 185). V tomto zmysle

${ }^{26}$ Tao Te t’ing je nielen klúčovým textom čínskej filozofickej, či dokonca spirituálnej tradície, ale dodnes patrí aj $\mathrm{k}$ najprekladanejším a najinterpretovanejším dielam čínskej filozofie. V našom akademickom prostredí možno za jedinečný pokladat' výklad tohto textu, ale aj procesu jeho vzniku a vývoja jeho úprav a interpretácií v kontexte čínskych dejín od M. Čarnogurskej (2009 a 2012). 
v súčasnosti dokonca možno hovorit’ o synkréze taoizmu, konfucianizmu ${ }^{27}$ a čínskeho marxizmu.

V prebiehajúcej diskusii o filozofických východiskách konceptu ekologickej civilizácie však zaznievajú aj kritické hlasy, ktoré poukazujú na to, že takáto interpretácia čínskej filozofickej tradície prakticky ignoruje rozsah environmentálnej devastácie, ktorá sprevádzala rozvoj čínskej agrárnej civilizácie od jej vzniku v staroveku. ${ }^{28}$

Aj viacerí slovenskí autori poukazujú na to, že klúčové heslo taoizmu wu-wej, teda nezasahovanie do prirodzeného chodu vecí, či ,konanie nekonaním“ malo pôvodne sociálno-politický význam, bolo adresované panovníkom ako návod na podla možnosti nenásilné vládnutie (Dubnička 2013, 189 - 190) a k jeho „zekologizovaniu“ došlo až v dvadsiatom storočí (Kučírek 2008, 30 - 32), a to dokonca najprv v západnom environmentalizme, ked’ tento pojem začala používat' morálna ekológia. $Z$ dejinno-filozofického hl'adiska teda pri pripisovaní „ekologických“ významov starovekým textom ide o anachronizmus. Ako upozorňuje Huertebise: „Anachronické interpretácie môžu vytvorit' pocit kontinuity, ktorý však často protirečí pôvodnému významu klasických textov a ich dobovému kontextu“29 (Huertebise 2017, 9). Podl'a neho dokonca neplatí ani argument, že v klasických textoch západnej filozofickej tradície nemožno nájst’ myšlienky s environmentálnym významom. Tie totiž vidí napríklad u Marca Aurelia, $\mathrm{v}$ renesančnom koncepte makrokozmu a mikrokozmu či u Schellinga. ${ }^{30} \mathrm{Tu}$ však treba namietnut', že tieto filozofické iniciatívy nikdy nedosiahli taký formatívny vplyv na západnú kultúru a jej vnímanie sveta, respektíve vzt’ahu človeka (spoločnosti, kultúry)

${ }^{27}$ Vysvetlenie nemožnosti liberálno-demokratických politických systémov odstránit' príčiny devastácie životného prostredia, a teda aj odvrátit' hroziaci kolaps planetárneho ekosystému z hl'adiska súčasného konfucianizmu podáva Ťiang Čching, jeden z najvýznamnejších konfuciánskych filozofov súčasnosti. Legitimita politického systému liberálnej demokracie je podl'a neho odvodzovaná od suverenity l'udu, ktorú chápe ako sekularizovanú verziu suverenity boha. Legitimita politického systému odvodzovaná len od suverenity l’udu je podl'a Čchinga príliš redukcionistická, vylučuje totiž možnost' legitimity posvätnej (transcendentnej) a legitimity historickej. Vôl'a l'udu sa totiž podl'a neho odvíja od l'udských túžob, zväčša krátkodobých, navyše aj l'ahko ovplyvnitel'ných (napr. marketingom, agitáciou, propagandou), ktorých obmedzovanie je (osobitne v konzumnej individualistickej spoločnosti, kde je právo vyrábat', spotrebovávat', a tým aj znečist'ovat' postavené nad právo na priaznivé životné prostredie) politicky nelegitímne. Presadzovanie dlhodobých celospoločenských záujmov, alebo dokonca záujmov celého l'udstva, je v takomto systéme vel'mi nepravdepodobné (Čching 2019, 22 - 24). Čching je vel'mi kritický k súčasnému politickému systému Číny, nehlási sa ani ku konceptu ekologickej civilizácie, ale jeho chápanie troch druhov legitimity a s nimi spojených troch druhov moci, ktoré by mali byt' reprezentované troma komorami parlamentu jasne odkazuje na pôvodnú taoistickú koncepciu sveta ako harmóniu troch základných prvkov - neba, zeme a človeka.

${ }^{28}$ Pre podrobnú analýzu environmentálnych dejín Číny pozri Elvin (2004). Pozri tiež Hansen, Li, Svarverud $(2018,198)$ a Ponting (2019).

${ }^{29}$ Túto námietku však možno vztiahnut' aj na západných autorov, ktorí sa prakticky o to isté pokúšajú novými interpretáciami a „aktualizáciami“ textov antickej či krest’anskej filozofie.

${ }^{30}$ Podl'a A. Gerea je dokonca pre konštituovanie filozoficky relevantného svetonázoru ako predpokladu reálnej transformácie industriálnej na ekologickú civilizáciu potrebné rekonštruovat' a aktualizovat' Schellingov špekulatívny naturalizmus a venovat' pozornost' jeho vývoju až po procesuálne metafyziky (Gare 2017b, 51-63). 
a prírody, ako to možno identifikovat' v súvislosti s čínskymi klasickými textami. Huertebis však tvrdí, že: „Pojem ,čínska ekologická civilizácia‘ môže byt' interným politickým nástrojom propagovaným tak, aby poskytol morálnu legitimitu vynucovaniu environmentálnych predpisov, ktoré by mohli mat’ nepriaznivé dopady na domácu ekonomiku“ (Huertebise 2017, 11). Odhliadnuc od toho, že práve v tomto západný environmentalizmus zlyháva, prehliada tiež, že tento koncept môže poskytovat' víziu, či dokonca normatívny obraz budúcnosti, o naplnenie ktorého sa možno usilovat' na individuálnej i celospoločenskej úrovni.

Práve to je to, čo podl'a Garea viacerým západným spoločnostiam chýba, a preto sa priemyselná civilizácia postavená na triumfe redukcionistického scientizmu a imperatívoch globálneho trhu nachádza uprostred najväčšej krízy, akej kedy l'udstvo čelilo, čím myslí nielen deštrukciu globálneho ekosystému, ale aj krízu filozofie, a tým aj filozofických základov kultúry a politického systému. Práve v tejto situácii je podl'a neho nevyhnutné obrátit' sa opät' k fillozofii, čo znamená oživit' a obnovit' filozofiu ako hl'adanie komplexného porozumenia l'udstvu a jeho miestu v prírode. Iba tak je podl'a neho možné nahradit' prevládajúci svetonázor, bez čoho sa nemožno vyhnút' globálnej ekokatastrofe (Gare 2017b, 13). Gare teda koncipovanie filozofie ekologickej civilizácie chápe ako kreovanie imaginácie, naratívu, či priamo kozmológie (Gare 2018, 226) postavenej na ekologickom, čo znamená predovšetkým evolučnom a symbiotickom, teda nie ekonomickom, teologickom či geopolitickom myslení, o ktoré sa opiera priemyselná civilizácia. Úlohou filozofie ekologickej civilizácie tak je prinajmenšom napomôct' „rozvinutiu úplne nových spôsobov porozumenia svetu, odhal'ujúcich jednotu v rozmanitosti a umožňujúcich l'ud'om lepšie porozumiet' sebe samým a ich miestu vo vesmíre" (Gare 2017b, 17). V jeho chápaní je tak koncept ekologickej civilizácie rovnako epistemickým, ako aj normatívnym manifestom, pozitívnou vizualizáciou možnej budúcnosti.

\section{Environmentálny autoritarianizmus či environmentálna demokracia}

Najostrejšia kritika konceptu ekologickej civilizácie však poukazuje na to, že predovšetkým jeho čínska verzia otvorene pracuje aj s konceptom environmentálneho autoritarianizmu. ${ }^{31}$ Je zjavné, že čínska vláda disponuje administratívnymi kapacitami a legislatívnymi právomocami, ktoré jej umožňujú realizovat' environmentálne politiky (napr. znižovanie emisií skleníkových plynov zatváraním uhol'ných baní a elektrární, zvyšovanie miery recyklácie, obmedzenie či úplný zákaz dovozu odpadu do krajiny či obmedzovanie komerčných aktivít $\mathrm{v}$ chránených územiach) ovel’a efektívnejšie a hlavne

\footnotetext{
${ }^{31}$ Jav, ktorý pomenoval M. Beeson (2010). Pred autoritarianiznom (a nacionalizmom) ako alternatívami ekologickej demokracie však už v čase liberálneho triumfializmu po páde východného bloku varoval R. Morrison (1995, 113 - 136).
} 
rýchlejši ${ }^{32}$ ako západné krajiny, ${ }^{33}$ pretože v tých je formulovanie, a hlavne presadzovanie environmentálnych politík silne ovplyvňované skupinovými záujmami,${ }^{34} \mathrm{ktorých}$ pôsobenie vládam fakticky znemožňuje naplnenie ich klimatických záväzkov vyplývajúcich z Parížskej klimatickej dohody (Xie, Pan 2018, 184 - 185).

R. Morrison však koncept ekologickej civilizácie kreuje z perspektívy demokracie, teda potreby jej prehĺbenia či rozšírenia do podoby ekologickej či environmentálnej demokracie. ${ }^{35}$ Zdôraznuje, že ekologická civilizácia má byt' budovaná na demokracii, rovnováhe a harmónii, čo znamená dostat' pod demokratickú kontrolu technologické a korporátne rozhodovacie procesy. Ekologická demokracia má byt' opakom, respektíve prekonaním súčasnej trhovej demokracie, ale aj industrializmu, teda situácie, v ktorej je väčšina rozhodnutí prijímaných cez prizmu trhovým a industriálnych imperatívov. Tie totiž „redukujú všetky aspekty života a pôdy na vstupy“ (Morrison 1995, 171) industrializovaných procesov produkcie. Základné imperatívy industrializmu nie sú kompatibilné s imperatívmi demokracie, takže demokracia v industriálnej civilizácii má nanajvýš podobu formálnych procedúr. V takejto forme je, rovnako ako sám industrializmus, dlhodobo neudržatel’ná. Transformácia industriálnej civilizácie na ekologickú je preto demokratizačným procesom, a zároveň nevyhnutným predpokladom pre dlhodobú udržatel'nost' demokracie ako politického systému.

Č́nski autori sú však skeptickí v súvislosti s reálnou možnostou prijímania potrebných environmentálnych opatrení demokratickými procedúrami. Tu možno identifikovat' aj hlavný rozdiel medzi západnou a čínskou verziou konceptu ekologickej civilizácie. Západná počíta s aktívnou participáciou environmentálne uvedomelej verejnosti, čínska naopak predpokladá, že je len vel'mi málo pravdepodobné, že by zástupcovia len priemerne, či skôr podpriemerne vzdelanej verejnosti, zameraní najmä na krátkodobý ekonomický rozvoj, boli schopní prijat' legislatívu, ktorá by dostatočne reflektovala aktuálne vedecké poznatky o klimatických zmenách a riziká, ktoré v ich dôsledku hrozia. ${ }^{36}$ Navyše, ako zdôrazňujú Schönfeld a Chen, čínsky politický systém kladie,

\footnotetext{
${ }^{32}$ Práve schopnost' presadzovat' environmentálne politiky, najmä znižovat' emisie skleníkových plynov čo najrýchlejšie, možno považovat' za kl'účový faktor, ktorý rozhodne o tom, či planetárny klimatický režim umožní d’alšiu existenciu civilizácie, či dokonca prežitie človeka ako živočíšneho druhu. Rozsah a rýchlost' prebiehajúcich klimatických zmien na jednej strane a pokračujúci rast emisií skleníkových plynov na druhej strane však ukazujú, že ani tie najradikálnejšie doteraz prijaté opatrenia nie sú dostatočné.

${ }^{33} \mathrm{~K}$ tomu pozri B. Gilley (2012).

${ }^{34}$ Teda lobingom (v lepšom prípade) ropných a uhol'ných korporácií, ale rovnako aj vel'kých automobiliek a $\mathrm{v}$ neposlednom rade zbrojného priemyslu.

${ }^{35}$ Popri konceptoch liberálnej, sociálnej a krest’anskej demokracie tak možno hovorit' aj koncepte environmentálnej demokracie.

${ }^{36}$ Opierajú sa pritom aj o skúsenosti z uplynulých štyridsiatich rokov transformácie, ked' práve implementácia trhových princípov v podobe slobody podnikania a kumulácie zisku a decentralizácia množstva kompetencií, a to aj tých v oblasti kontroly znečistenia a ochrany životného prostredia, viedli k zintenzívneniu exploatácie prírodných zdrojov a devastácii životného prostredia na lokálnej a regionálnej úrovni. Snaha centrálnej vlády presadzovat' politiku znižovania emisií skleníkových plynov
} 
na rozdiel od západného, kolektívne blaho na prvé miesto. ${ }^{37} \mathrm{Z}$ tohto pohl'adu preto musí byt' právo na priaznivé životné prostredie, dýchatelný vzduch, pitnú vodu či zdravé potraviny nadradené vlastníckemu právu či právu na podnikanie, ktoré implikuje právo na znečist’ovanie. Pokračujúca devastácia životného prostredia podla Schönfelda a Chena $(2019,9)$ vedie k otázke, či si civilizácia môže dovolit' pokračovat' v preferovaní občianskych slobôd pred kolektívnym blahom, ktorým je bezpochyby zachovanie obývatel'nosti planéty. Poukazujú totiž na to, že liberálne demokracie nielenže zlyhávajú v snahe regulovat' fosílne korporácie, ktoré sú zodpovedné za väčšinu emisií skleníkových plynov, ale dokonca poskytujú právnu ochranu tým, čo popierajú klimatické zmeny, spochybňujú vedecké poznatky o tomto procese a namiesto nich šíria dezinformácie a trhovú ideológiu (tamže).

Tento rozdiel vedie k viacerým otázkam. Je možné presadit' koncept ekologickej civilizácie demokraticky? Už len to, že tento koncept sa v roku 2007 stal súčast'ou ideológie KSČ a od roku 2018 je súčast'ou ústavy ČLR, vedie k pochybnostiam o jeho zlučitel'nosti so západnou predstavou ústavnej demokracie. Podl'a Huertebisa $(2017,17)$ je tento koncept len d’alším nástrojom na legitimizovanie nových foriem sociálnej kontroly jednotlivcov. Takáto kritika však neberie do úvahy, že závažnost' znečistenia a devastácie životného prostredia, a tým aj zhoršenie kvality ludského zdravia i čoraz intenzívnejšie prejavy klimatických zmien $v$ Číne (napokon aj na celom svete) si vyžadujú radikálne opatrenia. $\mathrm{K}$ nim určite patria prehodnotenie akceptovatel'ných spôsobov rozvoja, zmena imperatívov organizácie spoločnosti a v neposlednom rade aj hierarchie garantovaných práv, ale aj povinností či obmedzení vynucovaných verejnou mocou. ${ }^{38}$ To vedie k d’alším otázkam: Ako vybudovat' silné verejné inštitúcie, ktoré by

a zastavenie deforestácie masívnym programom zalesňovania opakovane narážajú na odpor predstavitel'ov miest a provincií, ktoré neraz neváhajú ignorovat' vládnu legislatívu, alebo aj skresl'ovat' štatistiky miery znečistenia či množstva vyprodukovaných emisií a odpadu, pretože za dôležitejší pokladajú hospodársky rast svojho mesta či regiónu a celoštátne, či dokonca globálne environmentálne problémy spôsobované takouto politikou vnímajú ako druhoradé (Gare 2012, 15 - 16).

${ }^{37} \mathrm{~K}$ podrobnej analýze čínskeho politického systému a silným vplyvom meritokratickej tradície $\mathrm{v}$ ňom, ktorá aj pomerne liberálnych čínskych autorov vedie k skepticizmu v súvislosti s možnostou presadenia, ale hlavne následného dlhodobého udržania systému západnej masovej demokracie v Č́ne. K tomu pozri Bell (2015). Z perspektívy súčasného konfucianizmu, ktorého tradícia je hlavným zdrojom meritokratického konceptu uplatňovaného v Č́ne v prístupe k politickým funkciám i k chápaniu zmyslu a úlohy politiky vo všeobecnosti, zase západnú formu demokracie kritizuje Ť. Čching (2019).

${ }^{38}$ Primárne nemusí íst' o obmedzenie vlastníckych práv či slobody podnikania alebo pohybu (cestovania). „Donútenie“ môže mat’ aj formu určených emisných limitov automobilov, tried energetickej efektivity spotrebičov, uhlíkovej dane či povinnosti recyklovat'. Akákol'vek právna norma, prikazujúca separovat' či recyklovat' odpad alebo čistit' odpadové vody či určujúca emisné limity spal'ovacích motorov atd'. je „donútením“ vynucovaným autoritou verejnej moci - nič z toho l'udia, a nieto ešte firmy, nerobili, kým im to zákon neprikázal a sankciami ich k tomu nedonútil. Zákony alebo emisné normy či normy určujúce prípustné množstvá rozličných chemikálií v pitnej vode či potravinách sú legálne formy donútenia. Jednotlivec nemá šancu kúpit' si auto s nižšími emisiami alebo chladničku s vyššou triedou efektívnosti, pokial' ju nikto nevyrába. Etika sebaobmedzenia (dobrovol'ná skromnost') môže jednotlivca viest' k tomu, že si auto, chladničku, práčku atd'. nekúpi, alebo nebude 
boli schopné presadzovat' verejný záujem, a zároveň zachovat' ich demokratickú kontrolu? A to v situácii, ked' existujúce inštitúcie, a neraz aj verejné politiky, primárne chránia a presadzujú súkromný, respektíve korporátny záujem v rozsahu, ktorý mnohých autorov vedie k tomu, že súčasný západný ekonomicko-politický systém označujú ako korporatokraciu. Pritom rozličné vedecké konzíliá vrátane Medzivládneho klimatického panelu, a tiež mnohé občianske iniciatívy i celosvetové ochranárske hnutia poukazujú na to, že verejným záujmom je ochrana a obnova globálnych ekologických verejných statkov (ecological commons), ${ }^{39}$ ku ktorým bezpochyby patria stabilný klimatický systém či biodiverzita, a nie ochrana korporátnych investící do zariadení na tažbu a spracovanie uhlia, ropy či zemného plynu. Práve tomu je však rozličnými dohodami o vol'nom obchode a ochrane investícií podriadená politika väčšiny štátov.

\section{Záver}

Koncept ekologickej civilizácie vychádza z poznania toho, ako (nielen ludské) komunity transformujú svoje prostredie, aby rozšírili predpoklady svojej existencie. Rovnako však aj z poznania, že jednotlivé subjekty (fyzické, ekonomické, politické) nie sú od (planetárneho) životného prostredia oddelitel'né, a to teoreticky ani prakticky. Č́nski autori poukazujú na to, že toto poznanie získané súčasnou vedou bolo prinajmenšom anticipované $\mathrm{v}$ predporozumení svetu $\mathrm{v}$ tradičnom čínskom svetonázore, vyjadrenom v taoistickom učení.

Ciel'om konceptu je zabezpečenie dôstojného života pre všetkých l'udí, to však $\mathrm{v}$ rámci možností systému planéty Zem, ktorého zdroje a schopnost' absorbovat' dôsledky l'udských aktivít a nimi produkovaného znečistenia, sú konečné. Doterajšie modely civilizácie a jej extenzívneho rozvoja však práve závislost' od stavu planetárneho systému a konečnost' zdrojov i limitovanú schopnost' absorbovat' znečistenie neberú do úvahy. Koncept teda v konečnom dôsledku poukazuje na potrebu zmenit' globálny ekonomicko-politický systém tak, aby bol zlučitelný s limitmi planéty, aby si ich bol vedomý a rešpektoval ich ako konečné, neprekročitel'né červené čiary rozvoja, respektíve akýchkol'vek l'udských aktivít. To sa, prirodzene, nezaobíde bez obmedzení mnohých, doteraz samozrejmých činností - napríklad spôsobov podnikania či trávenia vol'ného času.

Reálne vládne politiky, rovnako ako biznis stratégie globálnych korporácií, však idú presne opačným smerom - imperatívy rastu a priority zisku pritom d’alej prehlbujú

využivat' leteckú dopravu či odoberat' elektrinu vyrobenú spal'ovaním uhlia. Vyžadovat' taký asketizmus od všetkých je však utopizmus, ktorý by navyše spôsobil kolaps ekonomického systému. Rozličné formy obmedzenia či donútenia nie sú pritom cudzie ani západnému environmentalizmu. Napríklad H. Jonas tvrdí, že iba „najvyššia miera politicky vynútenej spoločenskej disciplíny dokáže podriadit' momentálnu výhodu dlhodobému príkazu zo strany budúcnosti“ (Jonas 1997, 211). Podl'a J. Lovelocka bude možno v záujme prežitia l'udstva nutné suspendovat' demokraciu (Lovelock 2014, 119 - 120). K environmentálnym limitom osobných slobôd pozri St’ahel (2016b), k problémom súčasného západného environmentalizmu a jeho východísk pozri St’ahel (2018).

${ }^{39} \mathrm{~K}$ tomu pozri Morrison $(1995,171-188)$. 
sociálny rozvrat i environmentálnu devastáciu. Odporujú tak snahám o zachovanie klimatického režimu zlučitel'ného s existenciou civilizácie a človeka ako živočíšneho druhu ako prvoradému verejnému záujmu v antropocéne. Koncept ekologickej civilizácie sa tieto javy usiluje nielen pomenovat', ale aj načrtnút' možné formy usporiadania spoločnosti organizovanej za základe imperatívu udržatel’nosti.

Už len dôsledná aplikácia tohto konceptu v samej Číne by vzhl'adom na množstvo jej obyvatel'ov a ich rastúcu kúpnu silu mala signifikantný vplyv na stav planetárneho ekosystému. V globalizovanom svete by však prísnejšie ekologické štandardy výroby a spotreby mali bezpochyby vplyv aj na iné krajiny, respektíve na ich environmentálne a priemyselné politiky. Z čisto filozofického hl’adiska je však klúčcovou otázka, či je možné presadit' koncept ekologickej civilizácie v západnom civilizačnom okruhu s jeho odlišnou ontológiou a chápaním človeka, spoločnosti a ich vzt’ahu s prírodou.

\section{Literatúra}

AHEARNE, G. (2013): Towards an Ecological Civilization: A Gramscian Strategy for a New Political Subject. Cosmos and History: The Journal of Natural and Social Philosophy, 9 (1), 317 - 326.

BEESON, M. (2010): The comming of environmental autoritarianism. Environmental Politics, 19 (2), $279-294$.

BELL, D. A. (2010): China's new Confucianism. Princeton: Princeton University Press.

BELL, D. A. (2015): The China Model: Political Meritocracy and the Limits of Democracy. Princeton: Princeton University Press.

BONDY, E. (1993a): Doslov. In: Lao-c': O Ceste Tao a jej tvorivej energii Te. Bratislava: Hevi, 97 - 104.

BONDY, E. (1993b): Ćínská filosofie. Praha: Vokno.

ČARNOGURSKÁ, M. (2009): Lao c' a proces vzniku Tao Te tïngu (I. diel). Bratislava: Veda.

ČARNOGURSKÁ, M. (2012): Lao c'a proces vzniku Tao Te tïngu (II. diel). Bratislava: Veda.

C̆CHING, Ť. (2019): Konfunciánský ústavni systém. Jak starověká minulost Číny může utvářet její politickou budoucnost. Praha: Filosofia.

DIAMOND, J. M. (2005): Collapse: How societies choose to fail or succeed. New York: Penguin Books.

DUBNIČKA, I. (2007): Mravy, šelmy a vegetariáni. Nitra: Univerzita Konštantína Filozofa.

DUBNIČKA, I. (2013): Šamani, mesiáši, proroci a reformátori. Nitra: Univerzita Konštantína Filozofa.

DUNAJ, L. (2013): Interkultúrny dialóg. In: Hrubec, M. a kol.: Kritická teorie společnosti. Český kontext. Praha: Filosofia, $161-198$.

DUNAJ, L. (2016): Towards critical aspects of Confucianism. Ethics \& Bioethics (in Central Europe), 6 (3 - 4), 135-145. DOI: https://doi.org/10.1515/ebce-2016-0016

DUNAJ, L. (2017): The Inner Conflict of Modernity, the Moderateness of Confucianism and Critical Theory. Human Affairs, 27, 466-484, DOI: https://doi.org/10.1515/humaff-2017-0038

DUNAJ, L. (2020): Axel Honneth v interkultúrnej perspektíve. Prípad Č́na. Politické Vedy, 23 (3) 118 -144. DOI: https://doi.org/10.24040/politickevedy.2020.23.3.118-144

ELVIN, M. (2004): The Retreat of the Elephants. An Environmental History of China. New Haven London: Yale University Press.

GARE, A. (2012): China and the Struggle for Ecological Civilization. Capitalism Nature Socialism, 23 (4), 10 - 26, DOI: https://doi.org/10.1080/10455752.2012.722306

GARE, A. (2013): Daoic Philosophy and Process Metaphysics. Overcoming the Nihilism of Western Civilization. In: Guo, Y. - Josifivic, S. - Lätzer-Lasar, A. (eds.): Metaphysical Foundations of 
Knowledge and Ethics in Chinese and European Philosophy. Paderborn: Wilhelm Fink, 111 136.

GARE, A. (2017a): From 'Sustainable Development' to 'Ecological Civilization': Winnig the War for Survival. Cosmos and History: The Journal of Natural and Social Philosophy, 13 (3), 130 - 153.

GARE, A. (2017b): The Philosophical Foundations of Ecological Civilization: A Manifesto for the Future. London: Routledge and Earthscan.

GARE, A. (2018): Ethics, Philosophy and the Environment. Cosmos and History: The Journal of Natural and Social Philosophy, 14 (3), $219-240$.

GILLEY, B. (2012): Autoritarian environmentalism and China's response to climate change. Environmental Politics, 21 (2), 276 - 294.

GORON, C. (2018): Ecological Civilization and the Political Limits of a Chinese Concept of Sustainability. China Perspectives, 26 (4), 39 - 52. Special Feature: Power and Knowledge in 21st Century China: Producing Social Sciences.

HABERL, H. et al (2020): A systematic review of the evidence on decoupling of GDP, resource use and GHG emissions, part II: synthesizing the insights. Environmental Research Letters 15 065003, DOI: https://doi.org/10.1088/1748-9326/ab842a

HANSEN, M. H., LI, H., SVARVERD, R. (2018): Ecological civilization: Interpreting the Chinese past, projecting the global future. Global Environmental Change, 53, 195 - 203. DOI: https://doi.org/10.1016/j.gloenvcha.2018.09.014

HORYNA, B. (2020): The Origins of Modern Cross-cultural European Interpretations of Chinese Philosophy. New Thoughts on China in the Work of G. W. Leibnitz. Human Affairs, 30, $146-$ 163. DOI: https://doi.org/10.1515/humaff-2020-0015

HRUBEC, M. (2020a): From China's Reform to the World's Reform. International Critical Thought, 10 (2), 282 - 295. DOI: https://doi.org/10.1080/21598282.2020.1778969

HRUBEC, M. (2020b): The Historical Resources of China's Model: Relevance to the Present. Human Affairs 30, 134 - 145. DOI: https://doi.org/10.1515/humaff-2020-0014

HUERTEBISE, J.-Y. (2017): Sustainability and Ecological Civilization in the Age of Anthropocene: An Epistemological Analysis of the Phychosocial and "Culturalist" Interpretations of Global Environmental Risks. Sustainability, 9, 1331, DOI: https://doi.org/10.3390/su9081331

JIANG, B., BAI, Y., WONG, Ch. P., XU, X., ALATALO, J. M. (2019): China's ecological civilization program - Implementing ecological redline policy. Land Use Policy, 81, 111 - 114, DOI: https://doi.org/10.1016/j.landusepol.2018.10.031

JONAS, H. (1997): Princip odpovédnosti. Pokus o etiku pro technologickou civilizaci. Přel. B. Horyna a Z. Bígl. Praha: Oikoymenh.

KÖGLER. H.-H. - DUNAJ, L'. (2018): Beyond Ethnocentrism: Towards a Global Social Theory. In: Giri, A. K. (ed.): Social Theory and Asian Dialogues. Singapore: Palgrave Macmillan, 69 - 106.

KREUZZIEGER, M. (2019): Doslov. Konfucianizmus ve světě provázaných modernit. In: Čching, Ť. Konfunciánský ústavní systém. Jak starověká minulost Číny může utvářet její politickou budoucnost. Praha: Filosofia, 141 - 149.

KUČÍREK, J. (2008): Ekofilozofia včera, dnes a zajtra. Nitra: Univerzita Konštantína Filozofa.

LAO-C' (1993): O Ceste Tao a jej tvorivej energii Te. Bratislava: Hevi.

LEMCHE, J., MILLER, J. (2019): Global Capital, Local Conservation, and Ecological Civilization: The Tiejia Ecology Temple and the Chinese Daoist Association's Green Agenda. Religions, 10 , 580. DOI: https://doi.org/10.3390/rel10100580

LIPITSKIJ, V. S. (1984): Puti formirovanija ekologičeskoj kul'tury ličnosti v uslovjach zrelogo socializma. Vestnik Moskovskogo universiteta. Teoria naučnogo kommunizma, 12 (2), 40 - 47.

LOVELOCK, J. (2014): A Rough Ride to the Future. New York: The Overlook Press.

LU, Sh. (2017): The Ecological Era and Classical Chinese Naturalism: A Case Study of Tao Yuanming. Singapore: China Academic Library, Springer. 
MEADOWS, D. H., MEADOWS, D. L., RANDERS, J., BEHRENS, III. W. W. (1972): Limits to Growth: a report for the Club of Rome's project on the predicament of mankind. New York: Universe Books.

MILLER, J. (2017): China's Green Religion: Daoism and the Quest for Sustainable Future. New York: Columbia University Press.

MOELLENDORF, D. (2011): A Right to Sustainable Development. The Monist, 94 (3), 433 - 452.

MORRISON, R. (1995): Ecological democracy. Boston: South End Press.

OVERMYER, D. L. (1999): Náboženství Činy. Svět jako živý organizmus. Praha: Prostor.

PAN, J. (2016): China's Environmental Governing and Ecological Civilization. Beijing: China Social Science Press, Springer-Verlag GmbH. DOI: https://doi.org/10.1007/678-3-662-47429-7_2

PARKES, G. (2020): How to Think about the Climate Crisis. A Philosophical Guide to Saner Ways of Living. London: Bloomsbury.

PIAČEK, J. (2014): Sykriticizmus - filozofia konkordancie. Bratislava: Hronka.

PONTING, C. (2019): Zelené dějiny světa: Životní prostředí a kolaps velkých civilizací. Praha: Karolinum.

ROETZ, H. (2013): Chinese 'Unity of Man and Nature'. Reality or Myth? In: Meinert, C. (ed.): Nature, Environment and Culture in East Asia: The Challenge of Climate Change. Leiden: Brill, 23 - 39.

SCHÖNFELD, M., CHEN, X. (2019): Daoism and the Project of an Ecological Civilization or Shengtai Wenming 生态文明. Religions, 10, 630. DOI: https://doi.org/10.3390/rel10110630

SKLAIR, L. (2019): The corporate capture of sustainable development and its transformation into 'good Anthropocene' historical bloc. Civitas, 19 (2), 296 - 314. DOI: https://doi.org/10.15448/1984-7289.2019.2.31970

SŤAHEL, R. (2016a): Filozofia environmentálnej krízy globálnej priemyselnej civilizácie. In: Suša, O., St’ahel, R.: Environmentální devastace a sociální destrukce. Praha: Filosofia, 97 - 225.

SŤAHEL, R. (2016b): Environmental Limits of Personal Freedom. Philosophica Critica, 2 (1), 3 - 21, DOI: https://doi.org/10.17846/PC.2019.2.1.3-21

SŤAHEL, R. (2018): Environmentalizmus ako politická filozofia pre 21. storočie. Filozofia, 73 (1), 1 - 13.

SŤAHEL, R. (2019): Sustainable development in the shadow of climate change. Civitas, 19 (2), 337 353. DOI: https://doi.org/10.15448/1984-7289.2019.2.31971

UNEP (2016): Green is Gold: The Strategy and Actions of China's Ecological Civilization. [online] Dostupné na: https://reliefweb.int/sites/reliefweb.int/files/resources/greenisgold_en_20160519.pdf (Navštívené: 23. 5. 2020).

WIEDMANN, T., LENZEN, M., KEYßER, L. T. et al. (2020): Scientists' warning on affluence. Nature Communications, 11 (1), 3107. DOI: https://doi.org/10.1038/s41467-020-16941-y

WORLD COMMISSION ON ENVIRONMENT AND DEVELOPMENT (1987): Our Common Future. Oxford: Oxford University Press

XIE, Z., PAN, J. (2018): China's Road of Green Development. Beijing: Foreign Language Press.

Táto štúdia vznikla s podporou grantu VEGA č. 1/0291/18 Historicko-filozofická analýza environmentálneho myslenia, skúmanie jeho vplyvov na etické, právne a politické myslenie a jeho spoločenská odozva.

Richard St'ahel

Filozofický ústav SAV

Klemensova 19

81364 Bratislava 1

Slovenská republika

e-mail: richard.stahel@savba.sk

ORCID ID: https://orcid.org/0000-0002-1665-5795 